\title{
Nutrient Availability in Soil Amended with Pecan Wood Chips
}

\author{
Mohammed B. Tahboub and William C. Lindemann ${ }^{1}$ \\ Department of Plant and Environmental Sciences, MSC 3Q, New Mexico \\ State University, Las Cruces, NM 88003
}

\author{
Leigh Murray \\ University Statistics Center, MSC 3CQ, New Mexico State University, \\ P.O. Box 30001, Las Cruces, NM 88003
}

Additional index words. Carya illinoinensis, pruning wood, burning, environmental concerns, nitrogen immobilization, phosphorus, potassium

\begin{abstract}
Pecan [Carya illinoinensis (Wangenh.) K. Koch] pruning wood is usually burned, a practice that creates serious environmental concerns. Chipping and soil incorporation of prunings may be an alternative disposal method if nutrient immobilization is not a problem. Our objective was to determine if incorporation of pecan wood chips into soil would affect the availability of nitrogen $(N)$, phosphorus $(P)$, and potassium (K). Pecan wood chips were incorporated into a silty clay soil at rates of $0,4484,8968$, 13,452, and 17,936 $\mathrm{kg} \cdot \mathrm{ha}^{-1}$ in May or June 2002, 2003, and 2004. Some plots received $\mathrm{N}$ (ammonium sulfate) at a rate of $0,15.2,30.5,45.7$, and $61.0 \mathrm{~kg} \cdot \mathrm{ha}^{-1}$ to adjust the $\mathrm{C}: \mathrm{N}$ ratio of trimmings to 30:1. Wood chip incorporation did not significantly decrease inorganic $\mathrm{N}$ regardless of application rate or number of applications. When ammonium sulfate was added to balance the $C: N$ ratio, soil inorganic $N$ increased with the rate of wood chip application, also indicating that $\mathrm{N}$ immobilization did not occur. Soil-available $P$ and $K$ were not significantly affected after one, two, or three wood chip applications. Soil-available $K$ increased when ammonium sulfate was added to balance the $C: N$ ratio. Soil incorporation of pecan wood chips does not appear to immobilize $N$, P, or $K$, thus providing growers with an environmentally viable means of wood disposal.
\end{abstract}

Mechanical pruning of trees is becoming increasingly common in commercial pecan orchards. This practice generates considerable biomass. For example, in Doña Ana County, N.M., an estimated 25,500 tons of pecan pruning wood is produced annually (Cabral, 2005). Pruning wood is currently burned as an economic means of disposal. However, the New Mexico Environment Department and the U.S. Environmental Protection Agency are concerned with this practice and may restrain, prohibit, or otherwise control burning in the future (New Mexico Air Quality Bureau, 2003). Other disposal methods of pecan pruning wood such as mulching, composting, and the use of pecan wood as firewood are not economically feasible. The use of pecan wood chips as mulch around young, nonproducing pecan trees has been practiced and proven beneficial (Foshee et al., 1996, 1999; Smith et al., 2000). Nevertheless, mulching wood chips around productive trees interferes with field operations and especially harvesting (Foshee et al., 1996). Composting the wood would require even more input by producers for a

Received for publication 15 Aug. 2006. Accepted for publication 17 Oct. 2006.

A contribution of the New Mexico Agricultural Experiment Station, New Mexico State University. We thank the New Mexico Pecan Growers Association for their support.

${ }^{1}$ To whom reprint requests should be addressed; e-mailwlindema@nmsu.edu. product that has low economic value. Most of the pruning wood is too small in diameter to be sold as firewood. A disposal method for pecan pruning wood is needed that is economically viable and environmentally acceptable. Chipping and incorporation of pecan wood chips into the soil may be an alternative disposal method.

Although numerous studies have examined the effects of manure, biosolids, and other organic amendments to soil, few published reports exist that have examined the effect of wood chip incorporation on soil nutrient availability. Soil incorporation of woody residues has received limited agricultural attention in the past because of their high $\mathrm{C}: \mathrm{N}$ ratio and the risk of nitrogen $(\mathrm{N})$ immobilization. Recent interest in wood chip incorporation is the result of environmental rather than agricultural concerns.

As an alternative to burning, almond pruning wood has been chipped and incorporated into soil in areas of the San Joaquin Valley, Calif., for more than 14 years (Holtz, 1999). The practice has gained acceptance because the waste is eliminated and can serve as a source of soil organic matter.

The addition of almond wood chips at a rate of one-third part wood chips to twothirds part soil to almond trees planted in the San Joaquin Valley initially reduced leaf petiole and soil nitrate levels in the first year, did not significantly reduce leaf petiole nitrate levels by the second year, and significantly increased both leaf petiole and soil nitrate levels by the third year (Holtz et al., 2004). The initial immobilization of soil inorganic $\mathrm{N}$ in the first year could be partially explained by the high wood chip application rate that was $\approx 410,000 \mathrm{~kg} \cdot \mathrm{ha}^{-1}$ or one-third of soil weight. However, despite the initial $\mathrm{N}$ immobilization when almond wood chips were first added to the soil, as the wood chips fully decomposed, they eventually returned nutrients to the soil.

Sanborn et al. (2004), while studying the effect of wood chip incorporation on the rehabilitation of older landings and roads constructed on fine-textured soils in British Columbia, Canada, found that the wood chip treatment, compared with subsoiling and shallow tillage, resulted in the highest 3-year growth rates of hybrid white spruce; leaf tissue analysis also indicated that macroand micronutrient concentrations were adequate. Based on these promising early results, the authors recommended silviculturists to use chipped wood wastes in the rehabilitation of disturbed lands.

Nitrogen mineralization is the conversion of organic $\mathrm{N}$ to mineral forms that are available for plant uptake, whereas $\mathrm{N}$ immobilization is the conversion of inorganic $\mathrm{N}$ to organic forms that are generally unavailable for plant uptake (Krishna, 2002; Paul and Clark, 1989). The mineralization and immobilization of $\mathrm{N}$ and other inorganic nutrients in soil are of considerable importance to plant nutrition. Nitrogen mineralization and immobilization are largely determined by the $\mathrm{C}: \mathrm{N}$ ratio of the substrate organic matter (Paul and Juma, 1981; Van Veen et al., 1984). At optimum environmental conditions, if the incorporated organic matter has a high $\mathrm{N}$ content (low C: N ratio) such as in fresh, green plant materials, the $\mathrm{N}$ content of the substrate is usually sufficient for microbial metabolism and the excess $\mathrm{N}$ is excreted to the soil. On the other hand, if the incorporated organic matter has a low $\mathrm{N}$ content (high $\mathrm{C}: \mathrm{N}$ ratio) such as in straw and wood, insufficient $\mathrm{N}$ exists in the substrate for microbial metabolism and microorganisms must use $\mathrm{N}$ from the soil (Coyne, 1999; Herrmann, 2003). Absorption of inorganic $\mathrm{N}$, and possibly other nutrients, from soil by microorganisms competes with plants for inorganic $\mathrm{N}$ and may result in $\mathrm{N}$ deficiency of plants growing in the soil.

Assuming optimum environmental conditions exist, the extent and length of the $\mathrm{N}$ immobilization process will depend on the $\mathrm{C}: \mathrm{N}$ ratio of the organic substrate, the quantity as well as physical size of the organic substrate added to the soil, and the resistance of the organic substrate to microbial attack that is a function of lignin, waxes, and fat present in the organic substrate (Alexander, 1998; Havlin et al., 1999). The C: $\mathrm{N}$ ratio is a good but not absolute indicator of $\mathrm{N}$ mineralization-immobilization turnover. Coyne (1999) indicated that some organic materials can have high $\mathrm{C}: \mathrm{N}$ ratios and still mineralize $\mathrm{N}$ because the effective $\mathrm{C}: \mathrm{N}$ ratio of their tissue is lower as a result of their high lignin content. Lignin is insoluble, hard to degrade, 
and has no direct effect on the metabolism of other substrates.

If soil incorporation of pecan wood can be shown not to interfere with harvest or compete with trees for nutrients, growers would be more likely to adopt chipping and soil incorporation as an alternative to burning. However, the influence of pecan wood chip incorporation must be viewed over several years and with repeated applications for a clear picture of the beneficial or detrimental effects of this disposal method. The purpose of this study was to determine the beneficial and detrimental effects of pecan wood incorporation on soil nutrient availability over several application rates and numbers of applications.

\section{Materials and Methods}

A field experiment was established at the Leyendecker Plant Science Research Center, New Mexico State University, Las Cruces, N.M., in May 2002. The experimental site (lat. $32^{\circ} 12.309^{\prime} \mathrm{N}$, long. $106^{\circ} 45.058^{\prime} \mathrm{W}$ ) is located $14.5 \mathrm{~km}$ south of Las Cruces at an elevation of $1172 \mathrm{~m}$. The mean annual precipitation is $20.3 \mathrm{~cm}$. The soil is a welldrained Glendale clay loam [fine-silty, mixed (calcareous), thermic Typic Torrifluvent] that formed in alluvium. The surface soil $(0$ to $30 \mathrm{~cm}$ ) has an average $\mathrm{pH}$ of 8.7 and an electrical conductivity of $2.24 \mathrm{dS} \cdot \mathrm{m}^{-1}$.

The experimental site consisted of four blocks. The experimental blocks were spaced $3.5 \mathrm{~m}$ apart. Each block consisted of three parallel sets of plots. The first set of plots received treatments in May 2002 only, the second set received treatments in June 2003 and May 2004, and the third set received treatments in May 2002, June 2003, and May 2004. Plots were $2.5 \times 2.5 \mathrm{~m}$ and $2.0 \mathrm{~m}$ apart from each other within each block.

Wood chips were obtained from Belding Farms, Fort Stockton, Texas. The pecan pruning wood was ground in a tub grinder to small chips. Two to four random wood chip samples for each year of application were analyzed for $\mathrm{N}$, phosphorus $(\mathrm{P})$, and potassium $(\mathrm{K})$ (Table 1$)$. The $\mathrm{N}$ content $(0.34 \%)$ of the pecan wood chips used in 2002 was used to estimate the $\mathrm{C}: \mathrm{N}$ ratio $(143: 1)$ of pecan wood based on an assumed $48.5 \%$ carbon content (Lamlom and Savidge, 2003). Five random wood chip subsamples for each year of application were collected and mixed into one composite sample. A representative sample taken from the composite sample was oven-dried at $65^{\circ} \mathrm{C}$ for $72 \mathrm{~h}$ to determine the moisture content, length, and diameter of the wood chips (Table 2). The wood chips were generally long and narrow.

Table 1. Total nitrogen, phosphorus, and potassium concentration of pecan wood chips applied in $2002(\mathrm{n}=3), 2003(\mathrm{n}=4)$, and $2004(\mathrm{n}=2)$.

\begin{tabular}{lccc}
\hline & \multicolumn{3}{c}{ Year } \\
\cline { 2 - 4 } Nutrient & $2002(\%)$ & $2003(\%)$ & $2004(\%)$ \\
\hline Nitrogen & 0.34 & 0.58 & 0.44 \\
Phosphorus & 0.03 & 0.03 & 0.04 \\
Potassium & 0.19 & 0.31 & 0.35 \\
\hline
\end{tabular}

Table 2. Length and diameter of pecan wood chips for the 3 years of application as a percent of total oven-dry weight $(\mathrm{n}=1)$.

\begin{tabular}{lccccc}
\hline & \multicolumn{5}{c}{ Length of Pecan Wood Chips $(\mathrm{cm})$} \\
\cline { 2 - 6 } Year & $<1.0(\%)$ & $1.0-2.5(\%)$ & $2.5-5.0(\%)$ & $5.0-10.0(\%)$ & $>10.0(\%)$ \\
\hline 2002 & 4.0 & 27.0 & 48.4 & 15.8 & 4.8 \\
2003 & 10.6 & 12.0 & 43.6 & 33.8 & 0.0 \\
2004 & 5.8 & \multicolumn{7}{c}{ 24.0 } & 38.5 & 31.7 & 0.0 \\
& \multicolumn{7}{c}{ Diameter of Pecan Wood Chips (mm) } \\
Year & $<2.0(\%)$ & $2.0-2.4(\%)$ & $2.4-4.8(\%)$ & $4.8-7.9(\%)$ & $>7.9(\%)$ \\
\hline 2002 & 14.0 & 7.0 & 25.7 & 25.5 & 27.8 \\
2003 & 15.4 & 7.0 & 25.1 & 20.3 & 32.2 \\
2004 & 8.0 & 5.9 & 35.1 & 34.3 & 16.7 \\
\hline
\end{tabular}

The experimental treatments were arranged in a control plus two-way factorial of four rates of wood chips and two inorganic $\mathrm{N}$ fertilizer treatments (an unfertilized treatment [N0] and a fertilized [N1] treatment to adjust the $\mathrm{C}: \mathrm{N}$ ratio of wood chips). The control was soil without wood chip or $\mathrm{N}$ fertilizer amendment. Wood chip application rates were $4484(\mathrm{C} 1), 8968(\mathrm{C} 2), 13,452$ (C3), and 17,936 (C4) $\mathrm{kg} \cdot \mathrm{ha}^{-1}$ and corresponded to the amount of pruning wood typically observed on the ground from light to heavy pruning. The experimental design was a randomized complete block with nine treatments and three application times (one application in 2002; two applications, one in 2003 and one in 2004; or three applications, one in 2002, one in 2003, and one in 2004). Each treatment was replicated four times. The experimental design permitted the measurement of the effect of one and two wood chip applications two times and the effect of three wood chip applications one time.

Pecan wood chips were incorporated (disking to $10 \mathrm{~cm}$ ) in May 2002, June 2003, and May 2004. The inorganic N (ammonium sulfate) treatment (N1) included rates of $\mathrm{N}$ at $15.2,30.5,45.7$, and $61.0 \mathrm{~kg} \cdot \mathrm{ha}^{-1}$ to adjust the $\mathrm{C}: \mathrm{N}$ ratio of wood chips to $30: 1$. Disking the soil in two opposite directions was performed immediately after applying the treatments. Disking was important to assure the quick infiltration of irrigation water, incorporation of treatments, and to avoid spreading fertilizer $\mathrm{N}$ and wood chips outside the research plots. Immediately after disking, the experimental site was flood-irrigated $(\approx 10 \mathrm{~cm})$ at low pressure for $4 \mathrm{~h}$ to avoid the movement of wood chips and fertilizer $\mathrm{N}$ with the irrigation water. Thereafter, the experimental site was flood-irrigated $(\approx 10 \mathrm{~cm})$ monthly throughout the length of the study. Glyphosate (Roundup herbicide; Monsanto, St. Louis, Mo.) was applied when necessary to control weeds.

Measured soil parameters included soil inorganic $\mathrm{N}\left(\mathrm{N}-\mathrm{NO}_{3}{ }^{-}+\mathrm{N}-\mathrm{NO}_{2}{ }^{-}\right.$and $\mathrm{N}-\mathrm{NH}_{4}{ }^{+}$), available $\mathrm{P}$, and $\mathrm{K}$. Soil samples for inorganic $\mathrm{N}, \mathrm{P}$, and $\mathrm{K}$ were taken at a depth of 0 to $20 \mathrm{~cm}$. Three soil subsamples were taken from each experimental plot. The soil samples were immediately air-dried for $72 \mathrm{~h}$, ground to pass through a $2.0-\mathrm{mm}$ sieve, and stored at $4{ }^{\circ} \mathrm{C}$ until analysis.

Nitrate and nitrite $\mathrm{N}$ were determined in 2.0 M KCl extracts on a Technicon Autoanalyzer II (Technicon, Tarrytown, N.Y.) (cadmium reduction method) (Maynard and
Kalra, 1993). Ammonium $\mathrm{N}$ was determined in $2.0-\mathrm{M} \mathrm{KCl}$ extracts by the Technicon Autoanalyzer II (indophenol blue method) (Maynard and Kalra, 1993). Soil inorganic N was monitored monthly from the summer through fall of 2002, 2003, and 2004 for the first set of plots that received one application in May 2002. For the plots that received two and three treatment applications, soil inorganic $\mathrm{N}$ was monitored monthly from the summer through fall of 2003 and 2004.

Soil-available $\mathrm{P}$ and $\mathrm{K}$ were measured in May 2003, 2004, and 2005 for the first set of plots that received one application in May 2002. For the plots that received two and three treatment applications, soil-available $\mathrm{P}$ and $\mathrm{K}$ were measured in May 2003 and 2004. Soil-available $\mathrm{P}$ and $\mathrm{K}$ were extracted by sodium bicarbonate (Olsen and Sommers, 1982) and ammonium acetate methods (Knudsen et al., 1982), respectively.

Soil measurements were analyzed by each set of plots and sampling time separately using analysis of variance SAS Proc Mixed (SAS Institute, 1999). Proc Mixed was used to calculate $F$ statistics for the overall treatment effect and for contrasts for the wood chip main effect, the $\mathrm{N}$ fertilization main effect, and for the wood chip simple effects with no N. The simple effects of the wood chips with no added $\mathrm{N}$ is a comparison among $\mathrm{C} 1 \mathrm{~N} 0, \mathrm{C} 2 \mathrm{~N} 0, \mathrm{C} 3 \mathrm{~N} 0$, and $\mathrm{C} 4 \mathrm{~N} 0$. In addition, means with standard errors were calculated for the nine treatments, and estimate statements were used to calculate wood chip and $\mathrm{N}$ main effect means and standard errors. Least square differences were used to carry out pairwise comparisons of the nine treatments to determine if they were significant at a significance level of $\alpha=0.05$.

\section{Results and Discussion}

From May to September after one, two, or three pecan wood chip applications, wood chips degraded to the point that no brittle wood chips remained to present mechanical problems during fall harvest, although large chips were still present. In September, the larger chips were generally soft and pliable. By May, 1 year after application, some wood chips were still evident in the soil and particularly at the higher application rates $\left(13,452\right.$ and $\left.17,936 \mathrm{~kg} \cdot \mathrm{ha}^{-1}\right)$. However, most of the smaller chips had degraded and the remaining chips were degraded to the point of flexible shreds. Those chips remaining 
tended to be short lengths of woody twigs that had passed unscathed through the tub grinder.

Inorganic soil $\mathrm{N}$ in the control and chipamended soil were not statistically different $(P>0.05)$ in the experimental plots that received only one application of wood chips in May 2002 for all sampling times except in Oct. 2004 (Fig. 1). Therefore, net immobilization of $\mathrm{N}$ was not observed in the plots that received one wood chip application for a period of 3 years. Net mineralization was observed at the end of the third year (Oct. 2004) after treatment application at the highest wood chip rate (Fig. 1). Soil inorganic N in control and chip-amended soil was not statistically different $(P>0.05)$ for a single application of wood chips in 2003 and no trend was apparent (data not shown). Average values for soil inorganic $\mathrm{N}$ in 2003 were $27.6 \pm 3.5,22.7 \pm 0.9,22.5 \pm 2.5,22.3 \pm$

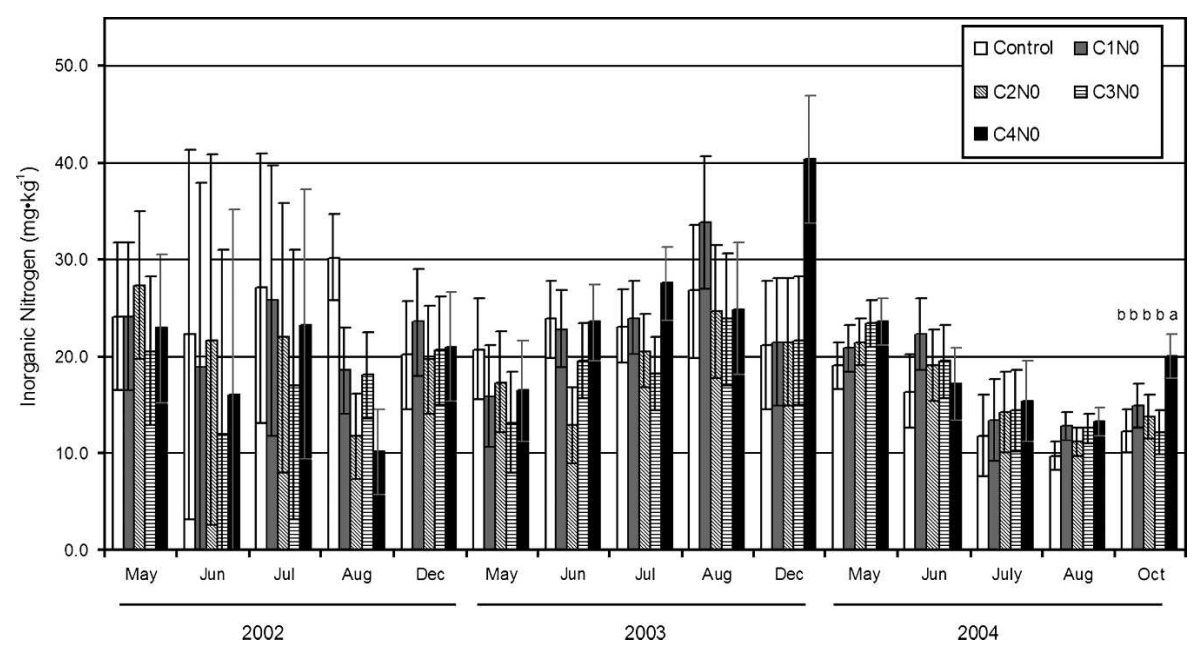

Fig. 1. Soil-inorganic nitrogen as influenced by wood chip amendment rates [wood simple effect with no added N (N0)]. Error bars represent \pm SE. Treatments with C1, C2, C3, and C4 received chips at 4484 $8968,13,452$, and $17,936 \mathrm{~kg} \cdot \mathrm{ha}^{-1}$ in the summer of 2002 , respectively. Only sampling dates significantly different at $\alpha=0.05$ have letters. Means with the same letter in each sampling date are not significantly different at $\alpha=0.05$.

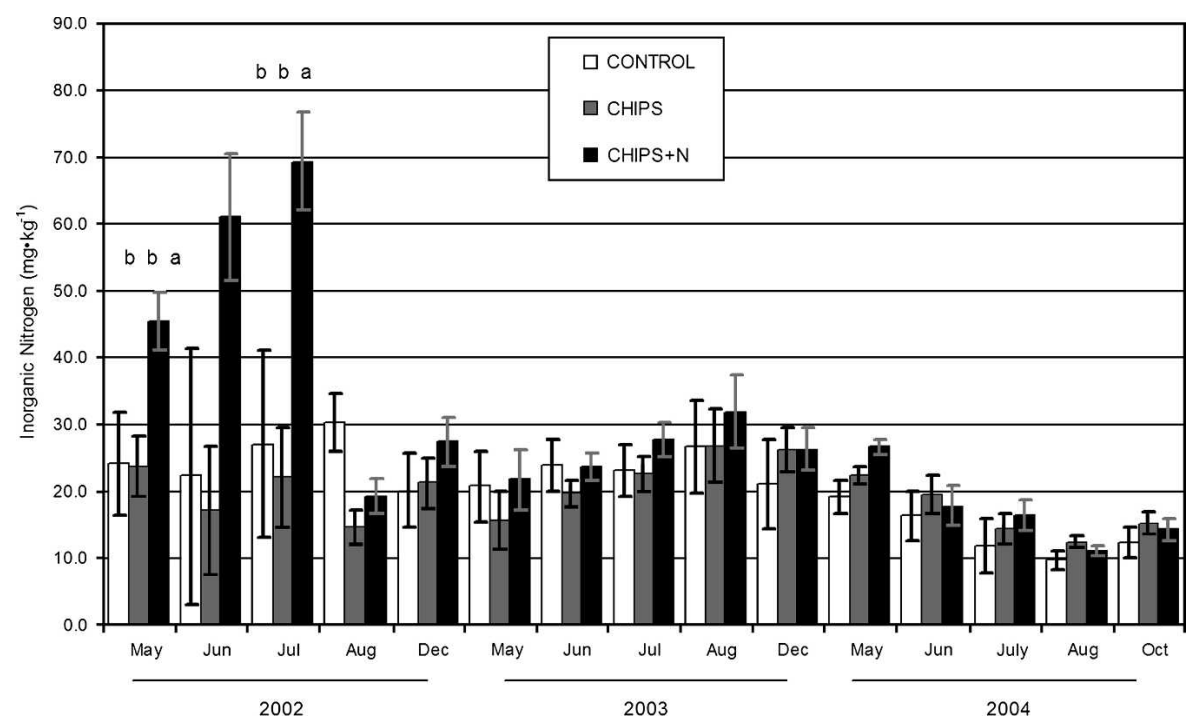

Fig. 2. Soil-inorganic nitrogen as influenced by the nitrogen treatments averaged over all other wood chip application rates. Treatments were applied in the summer of 2002. Error bars represent \pm SE. Only sampling dates significantly different at $\alpha=0.05$ have letters. Means with same letter in each sampling date are not significantly different at $\alpha=0.05$.
The addition of fertilizer $\mathrm{N}$ to balance the $\mathrm{C}: \mathrm{N}$ ratio of the pecan chips resulted in an increase in inorganic $N$ (Figs. 2, 3, and 4). Although no treatments included the addition of fertilizer $\mathrm{N}$ alone, the levels of soil inorganic $\mathrm{N}$ in the chip $+\mathrm{N}$-amended soil were high compared with the chip-amended soil. Had N immobilization occurred, soil inorganic $\mathrm{N}$ levels in the chip $+\mathrm{N}$-amended plots would have been more similar to the chip-amended plots.

The lack of $\mathrm{N}$ immobilization was attributed to the slow decomposition rate and size of pecan wood chips that limited the $\mathrm{N}$ needs of the microorganisms. The slow decomposition rate of pecan wood is mainly attributed to the high lignin content $(\approx 23 \%)$ in pecan wood (Pettersen, 1984). Lignin is a ratereducing factor in both the early and late stages of decomposition (Fioretto et al., 2005). The size of the wood chips also plays an important role in controlling the rate of pecan wood decomposition. Reducing the size of the wood chips by chopping or grinding to smaller pieces would result in a greater specific surface area. The greater the surface area of the wood chips, the faster the degradation rate because of the increased soil contact and exposure to microbial attack (Mackensen et al., 2003). Therefore, the hazard of inorganic $\mathrm{N}$ immobilization is greater with sawdust compared with wood chips.

The results of this study agree with the results obtained by Burgess et al. (2002) who found no net immobilization of $\mathrm{N}$ from organic residues with high $\mathrm{C}: \mathrm{N}$ ratios (149:1) when added to the soil. The authors indicated that the slow decomposition rates of the organic materials appeared to limit microbial $\mathrm{N}$ needs at any given time so that the net amount of $\mathrm{N}$ immobilized was very small and insignificant. Furthermore, Edmonds (1987) indicated that the critical $\mathrm{C}: \mathrm{N}$ ratio required for $\mathrm{N}$ release is a function of the substrate decomposition rates and that high critical $\mathrm{C}: \mathrm{N}$ ratios are not unexpected for decaying wood.

In contrast to what was observed in our study, Holtz et al. (2004) found that the incorporation of almond wood chips into a loamy sand soil placed in pots planted to almond trees resulted in an initial immobilization of soil inorganic $\mathrm{N}$ in the first year. The initial immobilization of soil inorganic $\mathrm{N}$ could be explained by the higher wood chip rate $\left(\approx 410,000 \mathrm{~kg} \cdot \mathrm{ha}^{-1}\right.$ or one-third of soil weight) compared with the highest wood chip rate $\left(17,936 \mathrm{~kg} \cdot \mathrm{ha}^{-1}\right)$ used in our study. Moreover, the size of the wood chips generated from the wood chipper was not stated and might have been smaller than wood chips produced by the tub grinder in our study.

Incorporation of pecan chips had no significant effect $(P>0.05)$ on soil-available $\mathrm{P}$ for the plots that received one, two, or three treatment applications at all sampling dates (Table 3). Phosphorus immobilization did not occur. The lack of significance of pecan wood chip incorporation on soil-available $\mathrm{P}$ was expected and attributed to the low concentration of $\mathrm{P}$ in pecan wood $(\approx 0.03 \% \mathrm{P})$. 


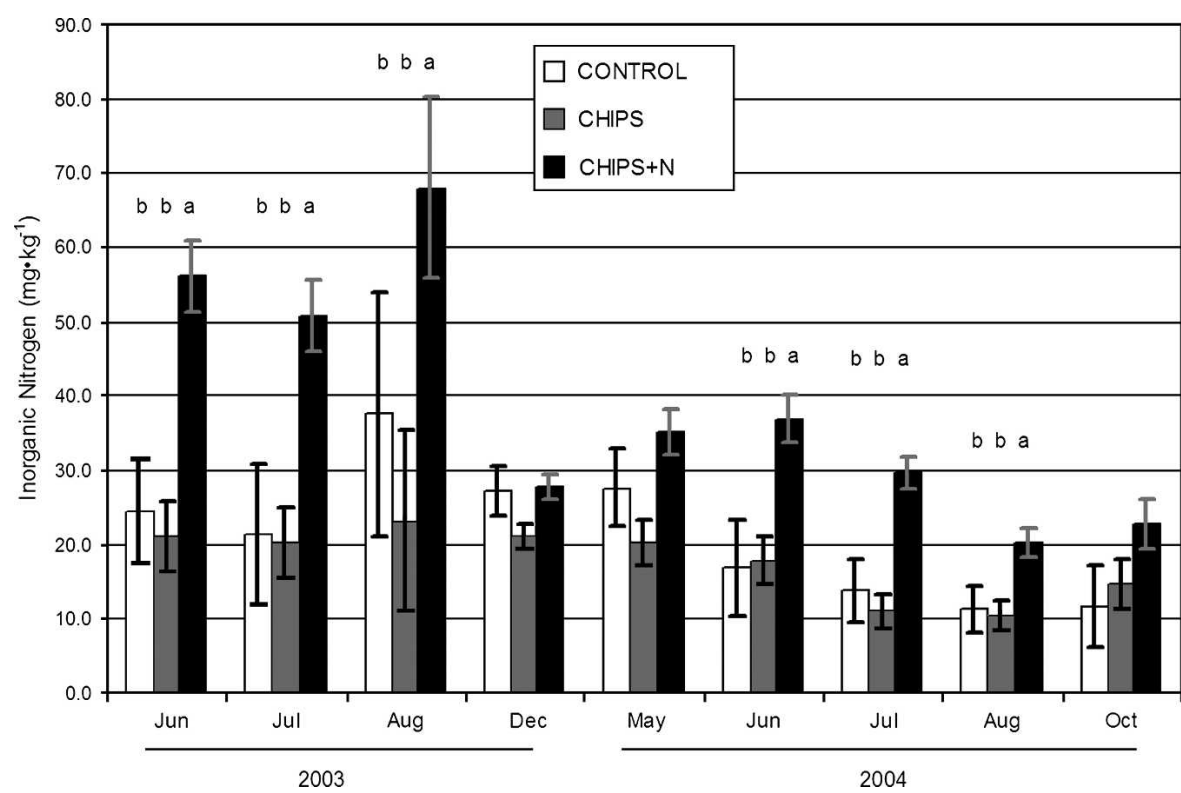

Fig. 3. Soil-inorganic nitrogen as influenced by the nitrogen treatments averaged over all other wood chip application rates. Treatments were applied in the summer of 2003 and 2004 . Error bars represent \pm SE. Only sampling dates significantly different at $\alpha=0.05$ have letters. Means with the same letter in each sampling date are not significantly different at $\alpha=0.05$.

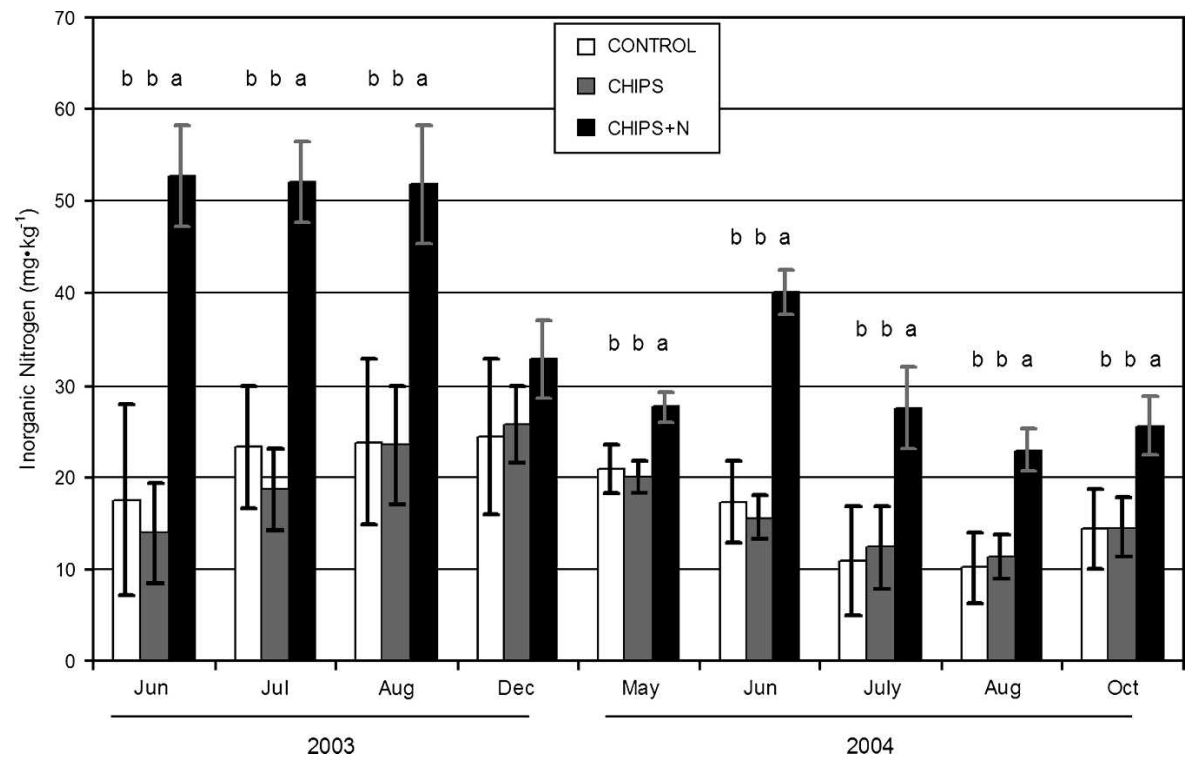

Fig. 4. Soil-inorganic nitrogen as influenced by the nitrogen treatments averaged over all other wood chip application rates. Treatments were applied in the summer of 2002, 2003, and 2004. Error bars represent \pm SE. Only sampling dates significantly different at $\alpha=0.05$ have letters. Means with the same letter in each sampling date are not significantly different at $\alpha=0.05$.

Table 3. Observed significance levels for the overall treatment effect on soil available phosphorus and potassium contents. ${ }^{2}$

\begin{tabular}{lccc}
\hline & Sampling & \multicolumn{2}{c}{ Observed Significance Level } \\
\cline { 2 - 4 } Number of Applications & Date & Phosphorus & Potassium \\
\hline One application in 2002 & May 2003 & 0.7535 & 0.6554 \\
& May 2004 & 0.1454 & 0.2821 \\
One application in 2003 & May 2005 & 0.3058 & 0.8716 \\
Two applications in 2002 and 2003 & May 2004 & 0.1488 & 0.8976 \\
Two applications in 2003 and 2004 & May 2004 & 0.2381 & 0.0099 \\
Three applications in 2002, 2003, and 2004 & May 2005 & 0.8267 & 0.0060 \\
\hline
\end{tabular}

${ }^{\mathrm{z}}$ Numerator and denominator $\mathrm{df}$ are 8 and 24 for each $\mathrm{F}$ test, respectively.

The expected amounts of macronutrients that will return to the soil on full decomposition at various application rates are given in Table 4.
The expected levels of total $P$ that will return to the soil at various application rates of pecan wood chips are relatively low and generally less than $8 \mathrm{~kg} \cdot \mathrm{ha}^{-1}$. The release of soil $\mathrm{P}$ to plant roots is controlled by several chemical and biologic processes. Most of the $\mathrm{P}$ added to soil as inorganic fertilizer and organic residues is rapidly bound by the soil minerals in chemical forms that are not subject to rapid release; thus, soil solution $P$ concentrations are typically very low (Blair and Boland, 1978). Furthermore, routine soil test methods carried out by soil laboratories do not measure the total quantity of $\mathrm{P}$ in the soil, but rather measure a part of those compounds that sustain plant-available $\mathrm{P}$ in the soil solution and thus may not assess the potential contribution of organic $\mathrm{P}$ and its transformations after the decomposition of organic residues (Salas et al., 2003). No statistical differences $(P>0.05)$ in soil-available $\mathrm{K}$ among all application rates were observed for the plots that received one chip application in May 2002 or June 2003 (Table 3 ). One treatment application of pecan wood chips did not influence soil-available $\mathrm{K}$ for a period of 3 years after one treatment application. The addition of ammonium sulfate to balance the $\mathrm{C}: \mathrm{N}$ ratio of pecan chips statistically increased soil-available $\mathrm{K}$ content 1 year after two and three treatment applications (Table 3; Fig. 5), but this increase is probably of marginal significance in terms of field management. However, soil-available K content in the control and chip-amended soil was not statistically different. Furthermore, no tendency was apparent $(P>0.05)$ for soilavailable $\mathrm{K}$ to increase with increasing wood chip application rate.

The ammonium sulfate fertilizer used to adjust the $\mathrm{C}: \mathrm{N}$ ratio of pecan wood chips is known to acidify soil (Havlin et al., 1999; Krishna, 2002). The increase in soil-available $\mathrm{K}$ content was attributed to a slight (but statistically significant) decrease in $\mathrm{pH}$ (8.8 to 8.6 , soil paste extract) with ammonium sulfate addition. Maximum $\mathrm{K}$ availability occurs when the soil $\mathrm{pH}$ is in the range of 6.0 to 7.0 (Havlin et al., 1999). Available K is held in soil around the negatively charged colloids in an exchangeable form and is somewhat pH-dependent (Havlin et al., 1999). Soil-exchangeable K decreases as soil $\mathrm{pH}$ goes below the optimum level as well as when the soil $\mathrm{pH}$ becomes greater than 7.0.

\section{Conclusions}

Soil incorporation of pecan wood chips had little effect on inorganic (plant-available) soil $\mathrm{N}, \mathrm{P}$, or $\mathrm{K}$ and therefore poses no significant $\mathrm{N}, \mathrm{P}$, or $\mathrm{K}$ immobilization risk. For N, this result is substantiated by the observation that the fertilizer $\mathrm{N}$ applied to balance the $\mathrm{C}: \mathrm{N}$ ratio of pecan wood chips was available for plant uptake and was not consumed by soil microorganisms. Potassium availability was increased when $\mathrm{N}$ was added to balance the $\mathrm{C}: \mathrm{N}$ ratio of pecan wood chips. However, wood chip amendment alone did not increase soil-available K. Pecan growers can incorporate chipped pecan pruning wood of the approximate size and rate (up to 17,936 $\mathrm{kg} \cdot \mathrm{ha}^{-1}$ ) used in this study as an alternative to 
Table 4. Concentration and amounts of Nitrogen, Phosphorus, and Potassium returned to soil at various application rates of pecan wood chips applied in 2002, 2003, and 2004.

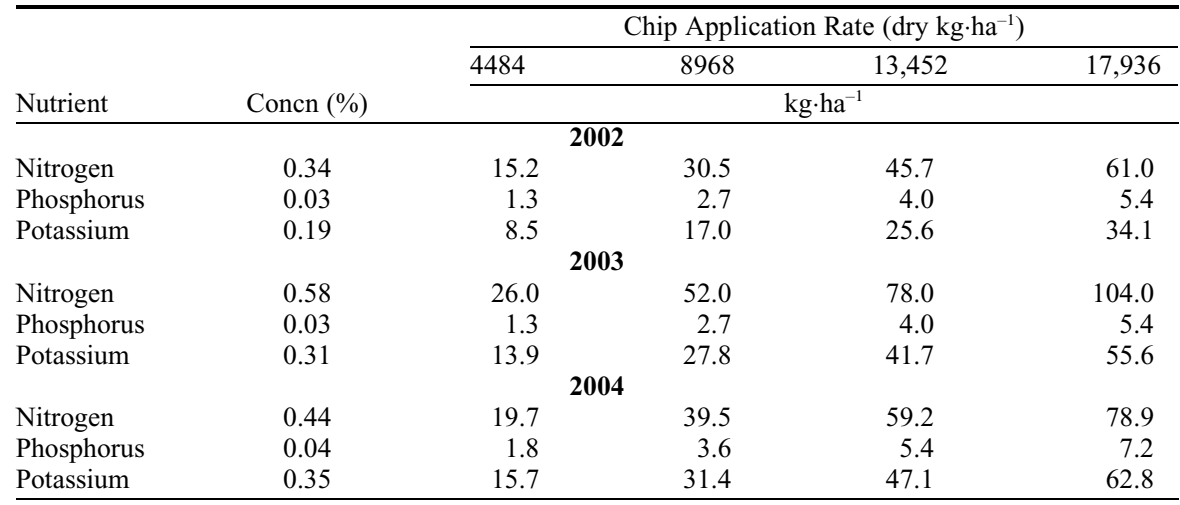

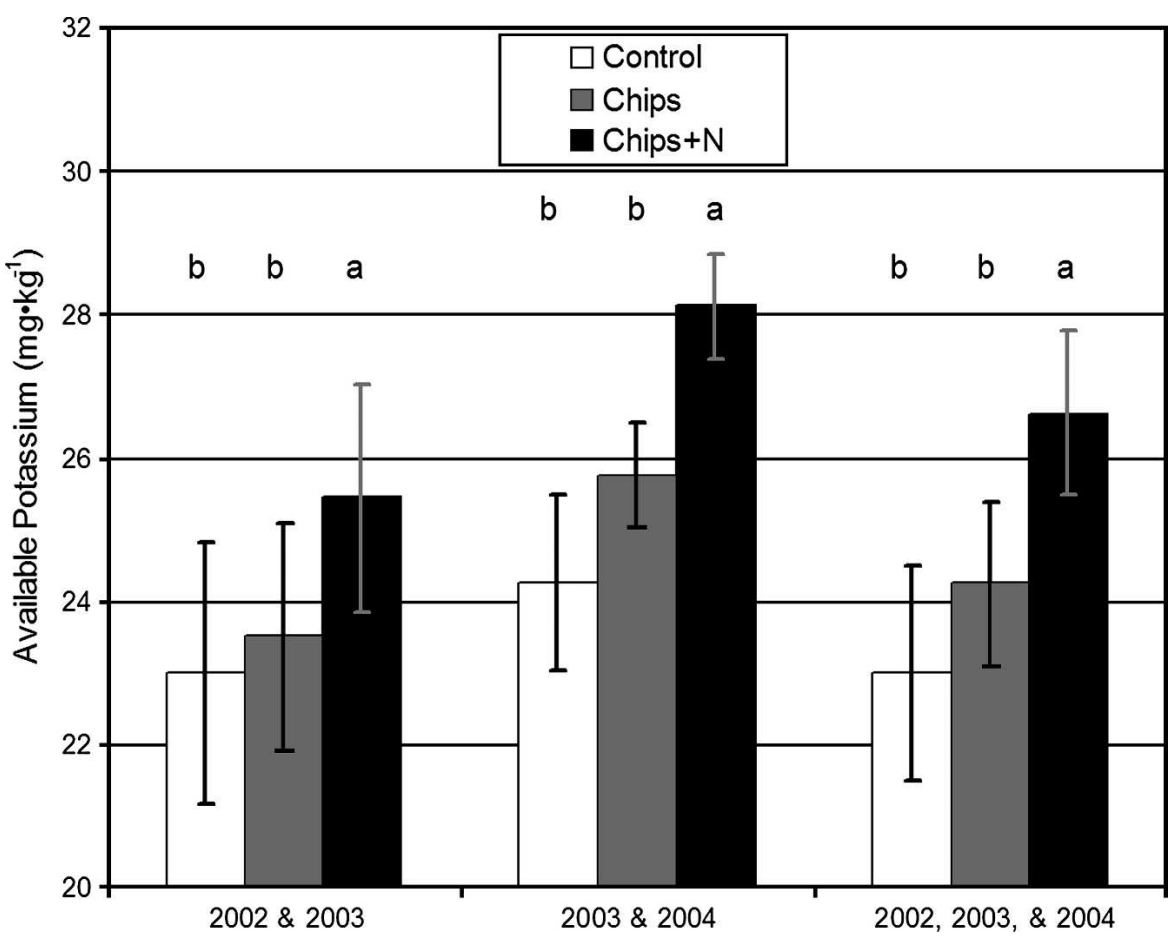

Fig. 5. Soil-available potassium 1 year after two and three treatment applications as influenced by the nitrogen treatments averaged over all other wood chip application rates. Error bars represent $\pm \mathrm{SE}$ Means with the same letter in each amendment date are not significantly different at $\alpha=0.05$.

burning without the fear of $\mathrm{N}, \mathrm{P}$, or $\mathrm{K}$ immobilization. Supplemental N fertilizer may be necessary when the physical size (smaller wood chips) and microbial environment encourage faster decomposition rates.

\section{Literature Cited}

Alexander, D.B. 1998. Bacteria and archaea, p. 44 71. In D.M. Sylvia, J.J. Fuhrmann, P.G. Hartel, and D.A. Zuberer (eds.). Principles and applications of soil microbiology. Prentice Hall, Upper Saddle River, N.J.

Blair, G.J. and O.W. Boland. 1978. The release of phosphorus from plant material added to soil. Aust. J. Soil Res. 16:101-111.

Burgess, M.S., G.R. Mehuys, and C.A. Madramootoo. 2002. Nitrogen dynamics of decomposing corn residue components under three tillage systems. Soil Sci. Soc. Am. J. 66:1350-1358.

Cabral, D. 2005. A feasibility study for alternatives for the commercial utilization of pecan wood waste from pruning New Mexico orchards. The New Mexico Manufacturing Extension Partnership, Albuquerque, N.M.
Coyne, D.L. 1999. Soil microbiology: An exploratory approach. Delmar Publishers, Albany, N.Y.

Edmonds, R. 1987. Decomposition rates and nutrient dynamics in small-diameter woody litter in four forest ecosystems in Washington. U.S. Can. J. For. Res. 17:499-509.

Fioretto, A., C. Di Nardo, S. Papa, and A. Fuggi. 2005. Lignin and cellulose degradation and nitrogen dynamics during decomposition of three leaf litter species in a Mediterranean ecosystem. Soil Biol. Biochem. 37:1083-1091.

Foshee, W.G., W.D. Goff, M.G. Patterson, K.M Tilt, W.A. Dozier, Jr., L.S. Tucker, and J.S. Bannon. 1999. Organic mulches affect soil and leaf nutrient levels of young pecan trees. J. Arboriculture. 25:81-83.

Foshee, W.G., W.D. Goff, K.M. Tilt, and J.D. Williams. 1996. Organic mulches increase growth of young pecan trees. HortScience 31:811-812.

Havlin, J.L., J.D. Beaton, S.L. Tisdale, and W.L. Nelson. 1999. Soil fertility and fertilizers: An introduction to nutrient management. Prentice Hall, Upper Saddle River, N.J.
Herrmann, A. 2003. Predicting nitrogen mineralization from soil organic matter-A chimera. Swedish Univ. of Agr. Sci., Dept. of Soil Sci., Uppsala, PhD Diss.

Holtz, B.A. 1999. Wood chipping to reduce air pollution and build soil organic matter, p. 100101.27th Annual Almond Industry Conf. Proc., 1-2 Dec. 1999. Almond Board of California, Modesto, Calif.

Holtz, B.A., M.V. McKenry, and T.C. CaesarTonThat. 2004. Wood chipping almond brush and its effect on the almond rhizosphere, soil aggregation and soil nutrients. Acta Hort. 638:127-137.

Knudsen, D., G.A. Peterson, and P.F. Pratt. 1982. Lithium, sodium, and potassium, p. 225-246. In A.L. Page, R.H. Miller, and D.R. Keeney (eds.). Methods of soil analysis: Part 2: Chemical and microbiological properties. Monograph Number 9, 2nd ed. ASA, Madison, Wis.

Krishna, K.R. 2002. Soil fertility and crop production. Science Publishers, Inc., Enfield, N.H.

Lamlom, S.H. and R.A. Savidge. 2003. A reassessment of carbon content in wood; variation within and between 41 North American species. Biomass and Bioenerg. 25:381-388.

Mackensen, J., J. Bauhus, and E. Webber. 2003. Decomposition rates of coarse woody debrisA review with particular emphasis on Australian tree species. Aust. J. Bot. 51:27-37.

Maynard, D.G. and Y.P. Kalra. 1993. Nitrate and exchangeable ammonium nitrogen, p. 25-38. In M.R. Carter (ed.). Soil sampling and methods of analysis. Can. Soc. Soil Sci., Lewis Publishers, Ann Arbor, Mich.

New Mexico Air Quality Bureau. 2003. Smoke management. Title 20, Chapter 2, Part 65. 31 Dec. 2003. <http://www.nmenv.state.nm.us/ aqb/regs/20_2_65nmac_123103.pdf>.

Olsen, S.R. and L.E. Sommers. 1982. Phosphorus, p. 403-430. In A.L. Page, R.H. Miller, and D.R. Keeney (eds.). Methods of soil analysis: Part 2: Chemical and microbiological properties. Monograph Number 9, 2nd ed. ASA, Madison, Wis.

Paul, E.A. and F.E. Clark. 1989. Soil microbiology and biochemistry. Academic Press, Inc., San Diego, Calif.

Paul, E.A. and N.G. Juma. 1981. Mineralization and immobilization of soil nitrogen by microorganisms, p. 179-195. In F.E. Clark, and T. Rosswall (eds.). Terrestrial nitrogen cycles, processes, ecosystems, strategies, and management impacts. Ecol. Bull. 33, Stockholm.

Pettersen, R.C. 1984. The chemical composition of wood, p. 57-126. In R. Rowell (ed.). The chemistry of solid wood. Am. Chem. Soc., Washington, D.C.

Salas, A.M., E.T. Elliott, D.G. Westfall, C.V. Cole, and J. Six. 2003. The role of particulate organic matter in phosphorus cycling. Soil Sci. Soc. Am. J. 67:181-189.

Sanborn, P., C. Bulmer, and D. Coopersmith. 2004. Use of wood waste in rehabilitation of landings constructed on fine-textured soils, central interior British Columbia, Canada. Western J. Appl. Forestry. 19:175-183.

SAS Institute Inc. 1999. SAS/STAT user's guide, version 8 . SAS Institute, Cary, N.C.

Smith, F.B. and P.E. Brown. 1990. Cellulose and lignin degradation in forest soils: Response to moisture, temperature, and acidity. Microb. Ecol. 20:289-295.

Smith, M.W., B.L. Carrol, and B.S. Cheary. 2000. Mulch improves pecan tree growth during orchard establishment. HortScience 35:192-195.

Van Veen, J.A., J.N. Ladd, and M.J. Frissel. 1984. Modeling $\mathrm{C}$ and $\mathrm{N}$ turnover through the microbial biomass on soil. Plant Soil 76:257-274. 